\title{
Analisis Daya Tampung Beban Pencemaran Kali Asem di Sekitar TPST Bantar Gebang dan TPA Sumur Batu
}

\author{
Opy Kurniasari a*, Lina Aprianti ${ }^{\text {b }}$ \\ ${ }^{a}$ Teknik Lingkungan Institut Teknologi Bandung, Jln Ganesa No 10 Bandung \\ ${ }^{b}$ Teknik lingkungan Institut Teknologi Nasional \\ *Email: kurniasariopy@gmail.com
}

Diterima (received) 13 Desember 2019; disetujui (accepted) 1 Februari 2020; tersedia secara online (available online) 1 Februari 2020

\begin{abstract}
The amount of waste management, especially in big cities and metropolitan areas, forms the basis for various policies. One of them is the Law of the Republic of Indonesia Number 18 Year 2008 concerning Solid Waste Management which mandates cooperation and partnerships between local governments, business entities, and the community in carrying out waste management. The carrying capacity of the environment should be one of the considerations in the preparation and determination of environmental management and recovery plans. However, in its implementation, the calculation of environmental carrying capacity is not easy. Therefore, planning is not based on environmental capability, but existing conditions, which are likely to have experienced degradation or exceeded carrying capacity. This condition is expected to cause a decrease in the carrying capacity of the environment around the Bantar Gebang TPST and Sumur Batu TPA, one of which is the Kali Asem river. Based on this, it is necessary to analyze the assimilative capacity of Kali Asem pollution around the TPST and TPA. The purpose of this study was to analyze the capacity of Asem River pollution load so that the ability of the environment in the area around TPST Bantargebang, Bekasi City to support the lives of humans and other living things. The results of laboratory analysis showed that at the initial sampling point, Kali Asem was already in a polluted condition which is characterized by high levels of BOD and COD.
\end{abstract}

Keywords: carrying capacity; assimilative capacity; pollution load; solid waste management

\begin{abstract}
Abstrak
Besarnya beban pengelolaan sampah khususnya di kota besar dan metropolitan melatar belakangi lahirnya berbagai kebijakan. Salah satunya adalah Undang-Undang Republik Indonesia Nomor 18 Tahun 2008 tentang Pengelolaan Sampah yang mengamanatkan adanya kerjasama dan kemitraan antar pemerintah daerah, badan usaha, dan masyarakat dalam melakukan pengelolaan sampah. Daya dukung lingkungan seharusnya menjadi salah satu pertimbangan dalam penyusunan dan penetapan rencana pengelolaan dan pemulihan lingkungan. Meskipun demikian, pada pelaksanaannya, perhitungan daya dukung lingkungan tidak mudah. Karena itu, perencanaan bukan berdasarkan pada kemampuan lingkungan, melainkan kondisi yang sudah ada, yang kemungkinan sudah mengalami degradasi atau sudah terlampaui daya dukungnya. Kondisi tersebut diperkirakan akan menimbulkan penurunan daya dukung lingkungan hidup di sekitar TPST Bantar Gebang dan TPA Sumur Batu, salah satunya adalah sungai Kali Asem. Berdasarkan hal tersebut perlu dilakukan analisis daya tampung beban pencemaran Kali Asem yang berada di sekitar TPST dan TPA tersebut. Tujuan penelitian ini adalah untuk menganalisis daya tampung beban pencemaran Kali Asem sehingga diketahui kemampuan lingkungan hidup di wilayah sekitar TPST Bantargebang Kota Bekasi untuk mendukung perikehidupan manusia dan mahluk hidup lainnya. Hasil analisis laboratorium menunjukkan bahwa pada titik awal pengambilan sampel, Kali Asem sudah dalam kondisi tercemar yaitu ditandai dengan tingginya kadar BOD dan COD.
\end{abstract}

Kata Kunci: daya dukung; daya tampung; beban pencemaran; pengelolaan sampah

doi: https://doi.org/10.24843/blje.2020.v20.i01.p04

(C) 2019 by the authors; Content from this work may be used under the terms of the Creative Commons Attribution 3.0 licence. Any further distribution of this work must maintain attribution to the author(s) and the title of the work, journal citation and DOI. Published under licence by Udayana University, Indonesia. 


\section{Pendahuluan}

Besarnya beban pengelolaan sampah khususnya di kota besar dan metropolitan melatar belakangi lahirnya berbagai kebijakan. Salah satunya adalah Undang-undang Republik Indonesia Nomor 18 Tahun 2008 tentang Pengelolaan Sampah yang mengamanatkan adanya kerjasama dan kemitraan antar pemerintah daerah, badan usaha, dan masyarakat dalam melakukan pengelolaan sampah.

Di Kota Bekasi terdapat TPA milik DKI Jakarta yang berlokasi di Bantar Gebang, serta TPA milik Pemerintah Kota Bekasi di Sumur Batu yang secara lokasi hampir berdekatan. Luas TPA Sampah Bantar Gebang adalah 110 Ha dan telah beroperasi sejak tahun 1989, dan diperkirakan jumlah sampah yang tertimbun telah mencapai lebih dari 30 juta ton, dengan ketinggian rata-rata mencapai 25 meter pada tiap zonanya. Adapun timbulan sampah dari DKI Jakarta yang masuk serta melalui jalan-jalan di Kota Bekasi mencapai 7000 ton per harinya. Peningkatan timbunan sampah yang akan meningkatkan produksi lindi menjadi masalah utama yang dihadapi di lingkungan Kecamatan Bantar Gebang terutama di Kelurahan Cikiwul, Ciketing Udik, dan Sumur Batu, sehingga masalah persampahan di Kota Bekasi saat ini masih belum dapat dipecahkan. Hal tersebut melatar belakangi studi ini sebagai upaya untuk memproyeksikan daya dukung lingkungan pada kurun waktu 20 tahun ke depan dengan memperhatikan rencana-rencana perkembangan Kota Bekasi.

Daya dukung lingkungan seharusnya menjadi salah satu pertimbangan dalam penyusunan dan penetapan rencana pengelolaan dan pemulihan lingkungan. Meskipun demikian, pada pelaksanaannya, perhitungan daya dukung lingkungan tidak mudah. Karena itu, perencanaan bukan berdasarkan pada kemampuan lingkungan, melainkan kondisi yang sudah ada, yang kemungkinan sudah mengalami degradasi atau sudah terlampaui daya dukungnya. Kondisi tersebut diperkirakan akan menimbulkan penurunan daya dukung lingkungan hidup di sekitar TPST Bantar Gebang dan TPA Sumur Batu, salah satunya adalah sungai Kali Asem. Berdasarkan hal tersebut perlu dilakukan analisis daya tampung beban pencemaran Kali Asem yang berada di sekitar TPST dan TPA tersebut.

\section{Metode Penelitian}

\subsection{Penentuan Titik Sampel}

Penelitian ini menggunakan metode deskriptif dengan pendekatan kuantitatif. Pendekatan kuantitatif digunakan dalam menganalisis kualitas air dan daya tampung beban pencemaran air sungai, serta membandingkan dengan baku mutu air berdasarkan Peraturan Pemerintah No 82 Tahun 2001 (Azwar, 2103). Pengambilan sampel juga menggunakan sistem grab sample, menurut Effendi (2003), grab sample adalah sample sesaat, dimana sampel diambil secara langsung dari badan air yang sedang dipantau, namun sampel ini hanya menggambarkan keadaan sungai pada saat pengambilan sampel dilakukan.

Jumlah titik sampling sangat tergantung pada debit rata-rata tahunan dan klasifikasinya. Selain itu jumlah titik pengambilan sampel juga sangat dipengaruhi oleh situasi dan kondisi air sungai. Pengambilan sampel kualitas air Kali Asem dilakukan sebanyak 5 titik yang terbagi menjadi bagian Hulu, bagian Tengah, dan bagian Hilir. Lokasi Pengambilan Titik Sampling dan Koordinat dapat dilihat pada Tabel 1 dan Gambar 1.

Tabel 1. Lokasi pengambilan titik sampling dan koordinat

\begin{tabular}{|c|c|c|c|}
\hline No & Titik Sampling & \multicolumn{2}{|c|}{ Koordinat } \\
\hline 1 & Kali Asem Titik 1 & $6^{\circ} 21^{\prime} 11.73 ” \mathrm{~S}$ & $106^{\circ} 59^{\prime} 49.99 ” \mathrm{~T}$ \\
\hline 2 & Kali Asem Titik 2 & $6^{\circ} 21^{\prime} 5.52 ” S$ & $106^{\circ} 59^{\prime} 56.02^{\prime \top}$ \\
\hline 3 & Kali Asem Titik 3 & $6^{\circ} 20^{\prime} 45.31$ ”'S & $107^{\circ} 0 ’ 2.02^{\prime \prime} \mathrm{T}$ \\
\hline 4 & Kali Asem Titik 4 & $6^{\circ} 20^{\prime} 33.04^{\prime \prime} \mathrm{S}$ & $107^{\circ} 0^{\prime} 5.68^{\prime \prime} \mathrm{T}$ \\
\hline 5 & Kali Asem Titik 5 & $6^{\circ} 20^{\prime} 33.38^{\prime \prime} \mathrm{S}$ & $107^{\circ} 0 ’ 9.83^{\prime} \mathrm{T}$ \\
\hline
\end{tabular}

Sumber: Hasil survei, 2018 


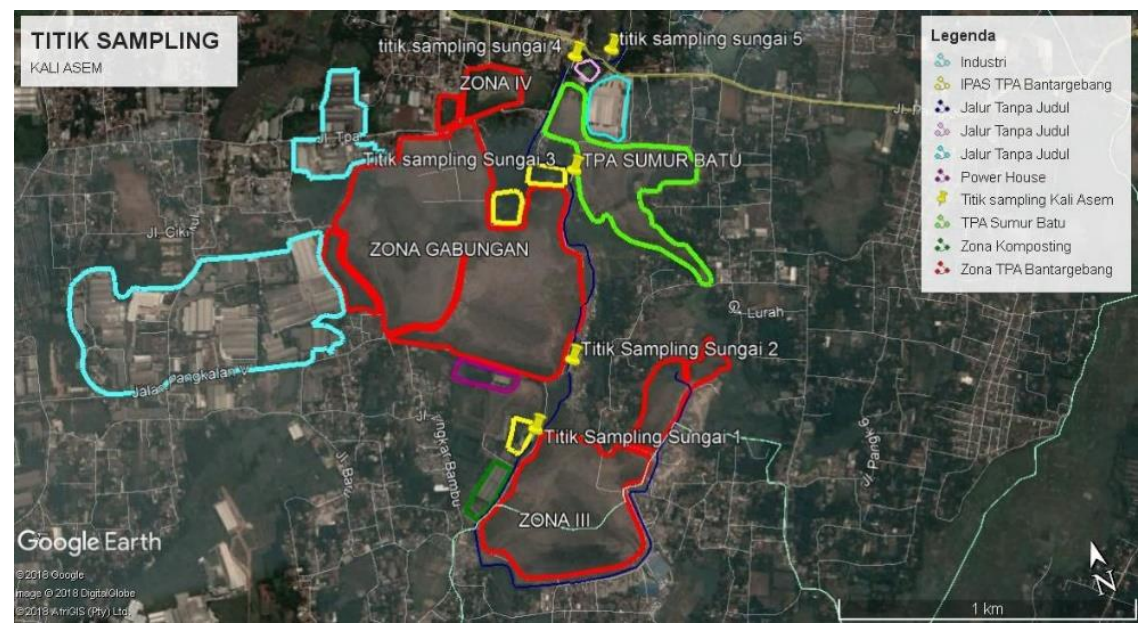

Gambar 1. Lokasi pengambilan sampling sungai kali asem.

\subsection{Sampling Kualitas Air}

Untuk mengetahui secara pasti mengenai kualitas air di setiap titik sampling maka diperlukan pengukuran kualitas air dan besaran beban pencemaran yang masuk yaitu debit air dan kualitas airnya. Musim kemarau adalah saat yang paling ideal untuk melakukan pengukuran kualitas air karena umumnya merupakan kondisi debit terkecil.

Seluruh kualitas air yang dipantau dibandingkan dengan baku mutu berdasarkan Peraturan Pemerintah No. 82 Tahun 2001 tentang Pengelolaan Kualitas Air dan pengendalian Pencemaran Air untuk kelas III. Penentuan status mutu air dengan menggunakan metode indeks pencemaran (pollution index) sesuai Keputusan Menteri Lingkungan Hidup No. 115 Tahun 2003, dengan menggunakan persamaan:

$$
P I_{j}=\sqrt{\frac{\left(C_{i} / L_{i j}\right)_{M}^{2}+\left(C_{i} / L_{i j}\right)_{R}^{2}}{2}}
$$

Dimana:

$\mathrm{PI}_{\mathrm{j}} \quad=$ Indeks Pencemaran bagi peruntukan $(\mathrm{j})$

$\mathrm{C}_{\mathrm{i}} \quad=$ Konsentrasi parameter kualitas air hasil pengukuran

$\mathrm{L}_{\mathrm{ij}} \quad=$ Konsentrasi parameter kualitas air yang dicantumkan dalam baku mutu peruntukan air ( $\mathrm{j}$ )

$\left(\mathrm{C}_{\mathrm{ij}} / \mathrm{L}_{\mathrm{ij}}\right)_{\mathrm{M}}=$ Nilai $\mathrm{C}_{\mathrm{ij}} / \mathrm{L}_{\mathrm{ij}}$ maksimum

$\left(\mathrm{C}_{\mathrm{ij}} / \mathrm{L}_{\mathrm{ij}}\right)_{\mathrm{R}}=$ Nilai $\mathrm{C}_{\mathrm{ij}} / \mathrm{L}_{\mathrm{ij}}$ rata-rata

Hubungan indeks pencemaran dengan mutu perairan disajikan pada Tabel 2 sebagai berikut:

Tabel 2. Hubungan nilai Indeks Pencemaran (IP) dengan Status Mutu Air

\begin{tabular}{cc}
\hline Indeks Pencemaran & Mutu Perairan \\
\hline $0 \leq \mathrm{PI}_{\mathrm{j}} \leq 1,0$ & Kondisi Baik \\
$1,0<\mathrm{PI}_{\mathrm{j}} \leq 5,0$ & Cemar Ringan \\
$5,0<\mathrm{PI}_{\mathrm{j}} \leq 10$ & Cemar Sedang \\
$\mathrm{PI}_{\mathrm{j}}>10,0$ & Cemar Berat
\end{tabular}

Sumber: Kep.MENLH Nomor 115 Tahun 2003 


\subsection{Daya Tampung Beban Pencemaran Sungai Kali Asem}

Penentuan daya tampung beban pencemaran dapat ditentukan dengan cara sederhana yaitu dengan menggunakan metoda neraca massa. Model matematika yang menggunakan perhitungan neraca massa dapat digunakan untuk menentukan konsentrasi rata-rata aliran hilir (downstream) yang berasal dari sumber pencemar point sources dan non-point sources, perhitungan ini juga dapat digunakan untuk menentukan persentase perubahan laju alir atau beban polutan.

Jika beberapa aliran bertemu menghasilkan aliran akhir, atau jika kuantitas air dan massa konstituen dihitung secara terpisah, maka perlu dilakukan analisis neraca massa untuk menentukan kualitas aliran akhir dengan perhitungan:

$$
C_{R}=\frac{\sum C_{i} Q_{i}}{\sum Q_{i}}=\frac{\sum M_{i}}{\sum Q_{i}}
$$

Dimana:

$\mathrm{C}_{\mathrm{R}}=$ Konsentrasi rata-rata konstituen untuk aliran gabungan

$\mathrm{C}_{\mathrm{i}} \quad=$ Konsentrasi konstituen pada aliran ke-i

$\mathrm{Q}_{\mathrm{i}} \quad=$ Laju alir aliran ke-i

$\mathrm{M}_{\mathrm{i}} \quad=$ Massa konstituen pada aliran ke-i

Metoda neraca massa ini dapat juga digunakan untuk menentukan pengaruh erosi terhadap kualitas air yang terjadi selama masa konstruksi atau operasional suatu proyek, dan dapat juga digunakan untuk suatu segmen aliran, suatu sel pada danau, dan samudera. Tetapi metoda neraca massa ini hanya tepat digunakan untuk komponen-komponen yang konservatif yaitu komponen yang tidak mengalami perubahan (tidak terdegradasi, tidak hilang karena pengendapan, tidak hilang karena penguapan, atau akibat aktivitas lainnya) selama proses pencampuran berlangsung seperti misalnya garam-garam. Penggunaan neraca massa untuk komponen lain, seperti DO, BOD, dan $\mathrm{NH}_{3}-\mathrm{N}$, hanyalah merupakan pendekatan saja.

\section{Hasil dan Pembahasan}

\subsection{Analisis Daya Tampung Beban Pencemaran Kali Asem dengan Metoda Neraca Massa}

Perhitungan neraca massa berdasarkan Lampiran I Keputusan Menteri Lingkungan Hidup No. 110 Tahun 2003 tentang Pedoman Penetapan Daya Tampung Beban Pencemaran Air pada Sumber Air, digunakan untuk menentukan konsentrasi rata-rata aliran hilir (down stream) Kali Asem yang berasal dari kegiatan pemrosesan akhir sampah yaitu dari TPST Bantar Gebang dan TPA Sumur Batu.

Penggunaan neraca massa menggunakan parameter COD, BOD, dan TSS dengan asumsi pencemaran akibat masuknya zat-zat organik yang biodegradable dan non-biodegradable dari kegiatan TPST Bantar Gebang dan TPSA Sumur Batu. Langkah-langkah penentuan beban daya tampung Kali Asem adalah sebagai berikut:

1. Mengukur konsentrasi setiap konstituen dan debit pada aliran sungai di bagian hulu kegiatan pemrosesan akhir sampah;

2. Mengukur konsentrasi setiap konstituen dan debit pada setiap outlet IPAS Bantargebang dan IPAS Sumur Batu;

3. Tentukan konsentrasi rata-rata pada aliran akhir setelah aliran bercampur dengan sumber pencemar dengan perhitungan:

Profil aliran Kali Asem mengalir dari titik 1 menuju titik 10. Diantara titik 1 dan 10 tersebut terdapat tiga aliran lain yang masuk kealiran Kali Asem utama, yaitu aliran 2 (IPAS Zona 3 TPST Bantargebang), aliran 5 dan 6 (IPAS Zona gabungan TPST Bantargebang) dan aliran 9 (IPAS TPA Sumur Batu). Selanjutnya ditentukan aliran 11-2 sebagai aliran bercampur yang menggambarkan akumulasi campuran dari hulu TPST Bantargebang sampai hilir TPA Sumur Batu sebagai satu aliran yang sama. 


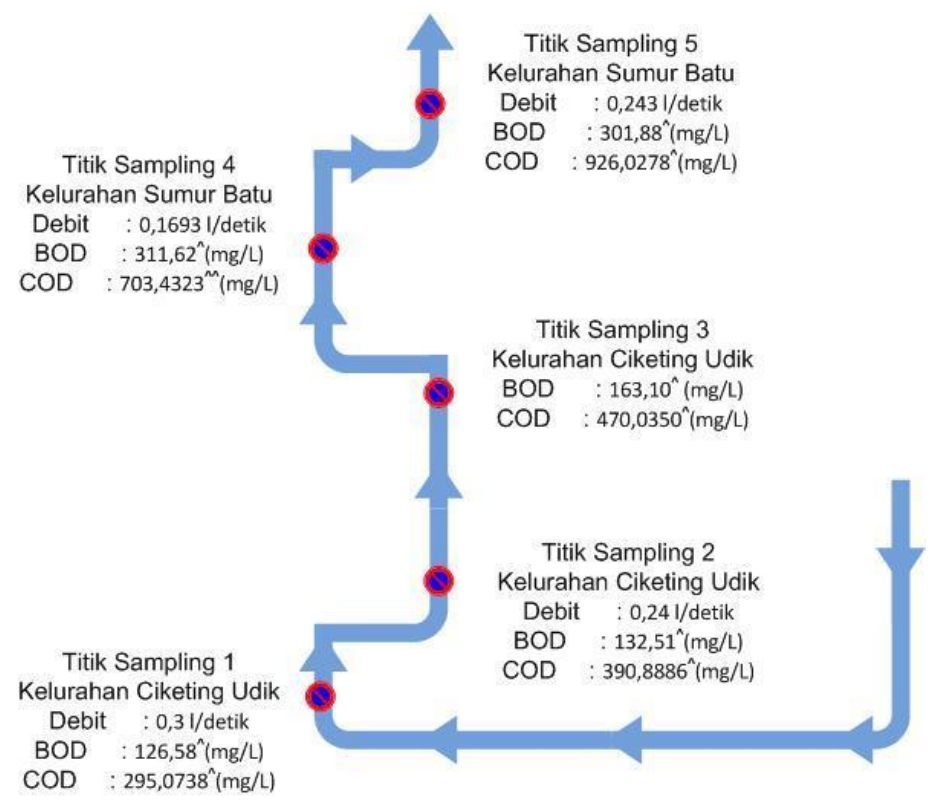

Gambar 2. Profil titik sampling Kali Asem.

Perhitungan indeks pencemaran juga dilakukan di setiap titik sampling 1 sampai dengan 5. Pengujian contoh air di sepanjang aliran Kali Asem mengacu kepada baku mutu sesuai peruntukan Kelas III PP No 82 Tahun 2001 menunjukkan telah terjadi penurunan kelas mutu air dari lokasi hulu TPST Bantargebang (titik 1) ke aliran hilir setelah TPA Sumur Batu (titik 5). Kaitan antara indeks pencemaran dan kelas mutu air disajikan dalan Tabel 3.

Tabel 3. Kelas mutu air Kali Asem setelah TPST Bantar Gebang dan TPA Sumur Batu.

\begin{tabular}{|c|c|c|c|c|c|c|}
\hline Titik & Lokasi & $\begin{array}{c}\text { Titik } \\
\text { Pengambilan } \\
\text { Sampel }\end{array}$ & $\begin{array}{c}\text { Kegiatan TPA dan } \\
\text { sekitarnya Sebelum } \\
\text { Melewati Titik } \\
\text { Sampel }\end{array}$ & $\begin{array}{c}\text { Parameter Tidak } \\
\text { Memenuhi BM Kelas } 3\end{array}$ & $\begin{array}{c}\text { Nilai } \\
\text { IP }\end{array}$ & Kelas \\
\hline \multirow{3}{*}{$\begin{array}{l}\text { TPST } \\
\text { Bantar } \\
\text { Gebang }\end{array}$} & $\begin{array}{c}\text { Kali Asem } \\
1\end{array}$ & $\begin{array}{c}\mathrm{S} 06^{\circ} 21^{\prime} 12,3^{\prime \prime} \\
\& \\
\text { E } 106^{\circ} 59^{\prime} 49,4^{\prime \prime}\end{array}$ & $\begin{array}{c}\text { Zona } 3 \text { TPST Bantargebang, } \\
\text { Zona komposting, } \\
\text { Bangunan IPAS }\end{array}$ & $\begin{array}{c}\mathrm{BOD}_{5}, \mathrm{COD}, \mathrm{DO}, \mathrm{P}, \mathrm{Cd}, \\
\mathrm{NO}_{2}, \mathrm{H}_{2} \mathrm{~S}, \text { Fecal Coli, } \\
\text { Coliform }\end{array}$ & 8 & $\begin{array}{l}\text { Cemar } \\
\text { Sedang }\end{array}$ \\
\hline & $\begin{array}{c}\text { Kali Asem } \\
2\end{array}$ & $\begin{array}{l}\mathrm{S} 06^{\circ} 21^{\prime} 05,7^{\prime \prime} \\
\& \mathrm{E} \\
106^{\circ} 59^{\prime} 56,2^{\prime \prime}\end{array}$ & $\begin{array}{l}\text { Outlet IPAS Zona 3, Zona } \\
\text { Gabungan }\end{array}$ & $\begin{array}{c}\text { TSS, } \mathrm{BOD}_{5}, \mathrm{COD}, \mathrm{DO}, \mathrm{P} \\
\mathrm{Cd}, \mathrm{NO}_{2}, \mathrm{H}_{2} \mathrm{~S}, \text { Minyak dan } \\
\text { Lemak, Detergen, Fecal Coli }\end{array}$ & 9 & $\begin{array}{l}\text { Cemar } \\
\text { Sedang }\end{array}$ \\
\hline & $\begin{array}{c}\text { Kali Asem } \\
3\end{array}$ & $\begin{array}{c}\text { S } 06^{\circ} 20^{\prime} 45,0^{\prime \prime} \\
\& \\
\text { E } 107^{\circ} 00^{\prime} 01,9^{\prime \prime}\end{array}$ & $\begin{array}{c}\text { Zona Gabungan, IPAS Zona } \\
\text { Gabungan, TPSA Sumur } \\
\text { Batu }\end{array}$ & $\begin{array}{c}\text { TDS, BOD } 5, \text { COD, DO, P, } \\
\text { Cd, } \mathrm{NO}_{2}, \mathrm{H}_{2} \mathrm{~S}, \text { Minyak dan } \\
\text { Lemak, Detergen, Fecal } \\
\text { Coli, Colifom }\end{array}$ & 12 & $\begin{array}{c}\text { Cemar } \\
\text { Berat }\end{array}$ \\
\hline \multirow{2}{*}{$\begin{array}{c}\text { TPSA } \\
\text { Sumur } \\
\text { Batu }\end{array}$} & $\begin{array}{c}\text { Kali Asem } \\
4\end{array}$ & $\begin{array}{l}\mathrm{S} 06^{\circ} 20^{\prime} 33,0^{\prime \prime} \\
\& \mathrm{E} \\
107^{\circ} 00^{\prime} 05,5^{\prime \prime}\end{array}$ & $\begin{array}{c}\text { Outlet IPAS Zona Gabungan, } \\
\text { TPSA Sumur Batu, Outlet } \\
\text { IPAS TPSA Sumur Batu }\end{array}$ & $\begin{array}{c}\text { TDS, BOD } 5, \text { COD, DO, P, } \\
\text { Cd, } \mathrm{NO}_{2}, \mathrm{H}_{2} \mathrm{~S}, \text { Minyak dan } \\
\text { Lemak, Detergen, Fecal } \\
\text { Coli, Colifom }\end{array}$ & 14 & $\begin{array}{c}\text { Cemar } \\
\text { Berat }\end{array}$ \\
\hline & $\begin{array}{l}\text { Kali Asem } \\
5\end{array}$ & $\begin{array}{l}\mathrm{S} 06^{\circ} 20^{\prime} 33,5^{\prime \prime} \\
\& \mathrm{E} \\
107^{\circ} 00^{\prime} 09,8^{\prime \prime}\end{array}$ & $\begin{array}{c}\text { Outlet IPAS TPSA Sumur } \\
\text { Batu, Industri }\end{array}$ & $\begin{array}{c}\text { TDS, BOD } 5, \text { COD, DO, P, } \\
\text { Cd, } \mathrm{NO}_{2}, \mathrm{H}_{2} \mathrm{~S}, \text { Minyak dan } \\
\text { Lemak, Detergen, Fecal } \\
\text { Coli, Colifom }\end{array}$ & 15 & $\begin{array}{c}\text { Cemar } \\
\text { Berat }\end{array}$ \\
\hline
\end{tabular}


Sumber: Hasil Uji Laboratorium dan Analisa dengan metode IP, 2018

Berdasarkan hasil perhitungan IP pada titik sampling Kali Asem 1 dan 2 dengan nilai $<10$ menyatakan kelas mutu cemar sedang, sedangkan semakin ke hilir yaitu dari titik 3 hingga titik 5 memiliki nilai meningkat yaitu IP $>10$ dengan kelas mutu cemar berat. Adapun kualitas air lindi setelah melewati IPAS baik TPST Bantar Gebang maupun TPA Sumur Batu telah memenuhi Peraturan Menteri LHK Nomor P.59/Menlhk/Setjen/Kum.1 /7/2016.

Lampiran I Tentang Baku Mutu Lindi. Sehingga diperkirakan ada pengaruh kegiatan pemrosesan akhir sampah pada zona 3 TPST Bantar Gebang, zona gabungan TPST Bantarg Gebang, dan zona TPA Sumur Batu terhadap penurunan kualitas air Kali Asem. Hasil perhitungan daya tampung berdasarkan parameter yang sama untuk setiap aliran disajikan pada Tabel 4.

Tabel 4. Analisis beban daya tampung Kali Asem

\begin{tabular}{|c|c|c|c|c|c|c|}
\hline \multicolumn{2}{|r|}{ Aliran } & $\begin{array}{c}\text { Titik Pengambilan } \\
\text { Sampel }\end{array}$ & $\begin{array}{c}\mathbf{Q} \\
\text { (Liter/detik) }\end{array}$ & $\begin{array}{c}\text { COD } \\
(\mathrm{mg} / \mathrm{L})\end{array}$ & $\begin{array}{l}\text { BOD } \\
(\mathrm{mg} / \mathrm{L})\end{array}$ & $\begin{array}{c}\text { TSS } \\
(\mathrm{mg} / \mathrm{L})\end{array}$ \\
\hline 1 & Aliran Dipengaruhi & Kali Asem 1 & 0,3 & 295,0738 & 126,58 & 178,00 \\
\hline 2 & TPST & IPAL Kolam IPAS III & 0,060 & 107,3012 & 56,44 & 52,00 \\
\hline 3 & \multirow{4}{*}{ Bantargebang } & Kali Asem 2 & 0,24 & 390,8886 & 132,51 & 476 \\
\hline 4 & & Kali Asem 3 & 40 & 470,035 & 163,1 & 158,00 \\
\hline 5 & & $\begin{array}{l}\text { IPAL Kolam IPAS II } \\
\text { (Zona Gabungan) }\end{array}$ & 0,071 & 171,2896 & 87,52 & 70,00 \\
\hline \multirow[t]{3}{*}{6} & & $\begin{array}{l}\text { IPAL Kolam IPAS II } \\
\text { (Zona Gabungan) }\end{array}$ & 0,057 & 170,9440 & 89,04 & 66,00 \\
\hline & 7 & $\begin{array}{c}\text { Aliran sungai bercampur } \\
\text { setelah TPST BG }\end{array}$ & 40,668 & 467,4948 & 162,4976 & 159,8183 \\
\hline & \multicolumn{2}{|c|}{ Baku Mutu Kelas 3} & - & 50 & 6 & 400 \\
\hline 8 & \multirow{3}{*}{$\begin{array}{l}\text { Aliran Dipengaruhi } \\
\text { TPA Sumur Batu }\end{array}$} & \multirow{3}{*}{$\begin{array}{c}\text { Kali Asem } 4 \\
\text { IPAL Kolam IPAS } \\
\text { Sumur Batu } \\
\text { Kali Asem 5 }\end{array}$} & 0,1693 & 703,4323 & 311,62 & 206,00 \\
\hline 9 & & & 0,0053 & 123,7216 & 63,68 & 46,00 \\
\hline 10 & & & 0,243 & 926,0278 & 301,88 & 330,00 \\
\hline & $11-1$ & $\begin{array}{c}\text { Aliran sungai berampur } \\
\text { setelah TPA SB }\end{array}$ & 0,4176 & 658,5992 & 228,7577 & 227,1455 \\
\hline & $11-2$ & $\begin{array}{c}\text { Aliran sungai akumulasi } \\
\text { Campuran setelah TPA } \\
\text { SB } \\
\end{array}$ & 41,0856 & 471,1347 & 163,9237 & 161,0005 \\
\hline \multicolumn{3}{|c|}{ Baku Mutu Kelas 3} & - & 50 & 6 & 400 \\
\hline
\end{tabular}

Sumber: Hasil Uji Laboratorium, 2018.

Sesuai dengan baku mutu Kelas 3, kondisi aliran pertama (titik 1) sudah dalam kondisi tidak memenuhi baku mutu dengan kategori cemar sedang. Selanjutnya perhitungan analisa daya tampung yang menggambarkan konsentrasi pencampuran di titik 7, 11-1 dan akumulasi pencampuran di titik 11-2, juga tidak memenuhi baku mutu perairan untuk BOD dan COD. Dengan demikian di titik 7, 11-1 dan titik akumulasi 11-2 tidak memiliki daya tampung lagi untuk parameter COD dan BOD. Sehingga sebaiknya air efluen IPAS dari TPST Bantargebang maupun TPA Sumur Batu tidak untuk dibuang ke badan air, melainkan dapat lakukan pengolahan tersier/lanjutan untuk keperluan pemanfaatan kembali untuk kegiatan di TPST Bantargebang dan TPA Sumur Batu.

\subsection{Analisis Daya Tampung Beban Pencemaran Kali Asem dengan Metoda Neraca Massa}

Kali Asem yang merupakan badan air penerima dari kegiatan TPST Bantar Gebang dan TPA Sumur Batu. Berdasarkan hasil observasi pada musim kering (Bulan Agustus-September 2018) aliran Kali Asem di bagian hulu dalam kondisi kering dan saat melewati zona 3 TPST Bantar Gebang mulai tampak adanya 
aliran air lindi ke Kali Asem. Dengan demikian sesuai dengan peruntukan Kali Asem untuk Kelas 3, maka dilakukan pengambilan sampel air Kali Asem di bagian hulu yaitu pada titik permulaan terlihat adanya aliran air sampai ke bagian hilir yang menunjukkan adanya pencampuran aliran dari efluen IPAS TPST Bantar Gebang, aliran selokan dari permukiman, efluen dari TPA Sumur Batu dan selokan dari industri. Pengambilan sampel air Kali Asem dilakukan pada 5 titik yaitu di bagian hulu Kali Asem yang dipengaruhi kegiatan TPST Bantar Gebang, bagian tengah Kali Asem yang menunjukkan pengaruh aliran campuran dari efluen IPAS Zona III dan IPAS I dan II serta permukiman penduduk, dan bagian hilir Kali Asem yang merupakan akumulasi pencampuran aliran dari efluen IPAS TPA Sumur Batu dan aliran selokan dari zona industri.

Tabel 4. Analisis beban daya tampung Kali Asem

\begin{tabular}{|c|c|c|c|}
\hline & Titik Lokasi & $\begin{array}{c}\text { Kegiatan TPA dan sekitarnya Sebelum } \\
\text { Melewati Titik Sampel }\end{array}$ & $\begin{array}{l}\text { Parameter Tidak Memenuhi BM } \\
\text { Kelas } 3\end{array}$ \\
\hline \multirow{3}{*}{$\begin{array}{l}\text { TPST Bantar } \\
\text { Gebang }\end{array}$} & Kali Asem 1 & $\begin{array}{c}\text { Zona } 3 \text { TPST Bantargebang, Zona } \\
\text { komposting, }\end{array}$ & $\begin{array}{c}\text { BOD5, COD, DO, P, Cd, } \mathrm{NO}_{2}, \mathrm{H}_{2} \mathrm{~S}, \\
\text { Fecal Coli, Coliform }\end{array}$ \\
\hline & Kali Asem 2 & Outlet IPAS Zona 3, Zona Gabungan & $\begin{array}{c}\text { TSS, BOD }, \text { COD, DO, P, Cd, } \mathrm{NO}_{2}, \\
\mathrm{H}_{2} \mathrm{~S} \text {, Minyak dan Lemak, Detergen, } \\
\text { Fecal Coli }\end{array}$ \\
\hline & Kali Asem 3 & $\begin{array}{c}\text { Zona Gabungan, IPAS Zona Gabungan, } \\
\text { TPSA Sumur Batu }\end{array}$ & $\begin{array}{c}\text { TDS, BOD }, \text { COD, DO, P, Cd, } \mathrm{NO}_{2}, \\
\mathrm{H}_{2} \mathrm{~S} \text {, Minyak dan Lemak, Detergen, } \\
\text { Fecal Coli, Colifom }\end{array}$ \\
\hline \multirow{2}{*}{$\begin{array}{c}\text { TPSA } \\
\text { Sumur Batu }\end{array}$} & Kali Asem 4 & $\begin{array}{l}\text { Outlet IPAS Zona Gabungan, TPSA Sumur } \\
\text { Batu, Outlet IPAS TPSA Sumur Batu }\end{array}$ & $\begin{array}{c}\text { TDS, BOD5, COD, DO, P, Cd, } \mathrm{NO}_{2}, \\
\mathrm{H}_{2} \mathrm{~S} \text {, Minyak dan Lemak, Detergen, } \\
\text { Fecal Coli Colifom }\end{array}$ \\
\hline & Kali Asem 5 & Outlet IPAS TPSA Sumur Batu, Industri & $\begin{array}{c}\text { TDS, BOD }, \text { COD, DO, P, Cd, } \mathrm{NO}_{2}, \\
\mathrm{H}_{2} \mathrm{~S} \text {, Minyak dan Lemak, Detergen, } \\
\text { Fecal Coli, Colifom }\end{array}$ \\
\hline
\end{tabular}

Sumber: Hasil Analisis, 2018.

\subsubsection{BOD}

Biochemical Oxygen Demand atau BOD adalah ukuran dari oksigen yang digunakan oleh mikroorganisme untuk menguraikan limbah ini. Jika ada jumlah besar sampah organik dalam air, juga ada banyak bakteri untuk menguraikan limbah ini. Sumber BOD dari bahan organik atau zat organik dari air limbah. Baku mutu BOD berdasarkan Peraturan Pemerintah No. 82 Tahun 2001 tentang Pengelolaan Kualitas Air dan Pengendalian Pencemaran Air Kelas III yakni 6 mg/L. Konsentrasi BOD di Kali Asem secara umum melebihi baku mutu BOD yang disyaratkan. Hal ini dapat dilihat pada Gambar 3. Konsentrasi BOD yang melebihi baku mutu disebabkan bahan pencemar organik yang tinggi. Sehingga pengurai seperti mikroorganisme membutuhkan oksigen yang besar untuk menguraikan bahan pencemar organik.

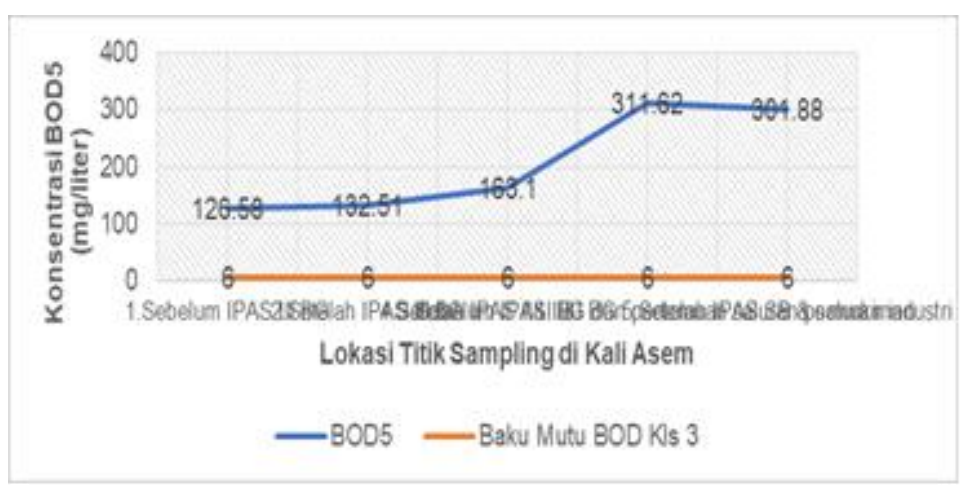


Gambar 3. Konsentrasi BOD Kali Asem dipengaruhi aktifitas TPA dan sekitarnya.

\subsubsection{COD}

Chemical Oxygen Demand (COD) merupakan jumlah oksigen yang dibutuhkan untuk mengoksidasi zat-zat organik yang ada dalam sampel air atau banyaknya oksigen yang dibutuhkan untuk mengoksidasi zat-zat organik menjadi $\mathrm{CO} 2$ dan $\mathrm{H} 2 \mathrm{O}$. Sumber COD dari bahan organik atau zat organik. Baku mutu COD berdasarkan Peraturan Pemerintah No. 82 Tahun 2001 tentang Pengelolaan Kualitas Air dan Pengendalian Pencemaran Air Kelas III yakni $50 \mathrm{mg} / \mathrm{L}$. COD berasal dari zat organik yang mudah terdegradasi dan zat organik yang sulit terdegradasi oleh mikroorganisme. Data hasil pengukuran COD lebih jelas disajikan pada Gambar 4.

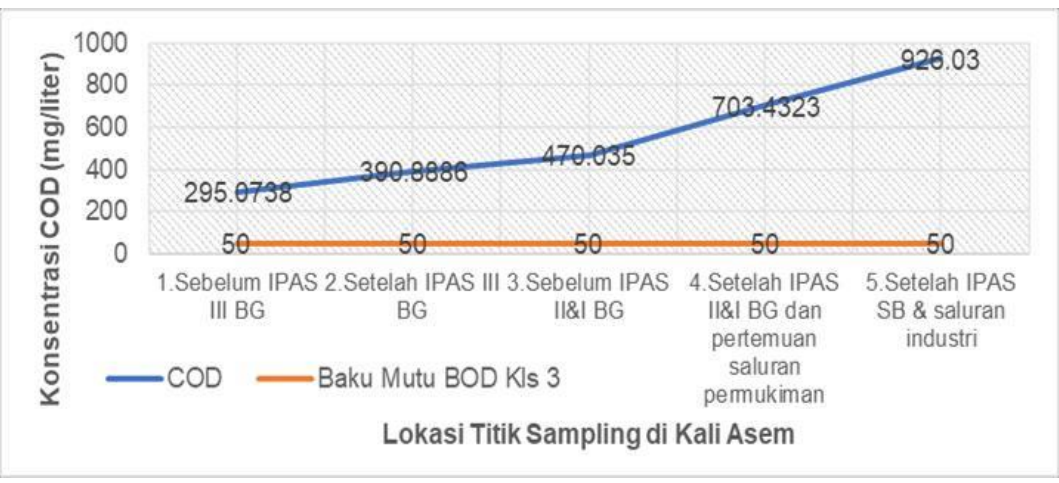

Gambar 4. Konsentrasi COD Kali Asem dipengaruhi aktifitas TPA dan sekitarnya.

\subsubsection{TSS}

Total suspended solid atau padatan tersuspensi total (TSS) adalah residu dari padatan total yang tertahan oleh saringan dengan ukuran partikel maksimal $2 \mu \mathrm{m}$ atau lebih besar dari ukuran partikel koloid. Yang termasuk TSS adalah lumpur, tanah liat, logam oksida, sulfida, ganggang, bakteri dan jamur. TSS memberikan kontribusi untuk kekeruhan (turbidity) dengan membatasi penetrasi cahaya untuk fotosintesis dan visibilitas di perairan. TSS yang disyaratkan berdasarkan Peraturan Pemerintah No. 82 Tahun 2001 tentang Pengelolaan Kualitas Air dan Pengendalian Pencemaran Air Kelas III yakni 400 $\mathrm{mg} / \mathrm{L}$. Berdasarkan hasil pengukuran TSS diketahui konsentrasi TSS di Kali Asem secara umum memenuhi baku mutu yang disyaratkan yaitu $<400 \mathrm{mg} / \mathrm{L}$, kecuali pada titik 2 yaitu titik lokasi setelah melewati zona pengomposan TPST Bantar Gebang dan Outlet IPAS III. Data hasil pengukuran TSS lebih jelas disajikan pada Gambar 5.

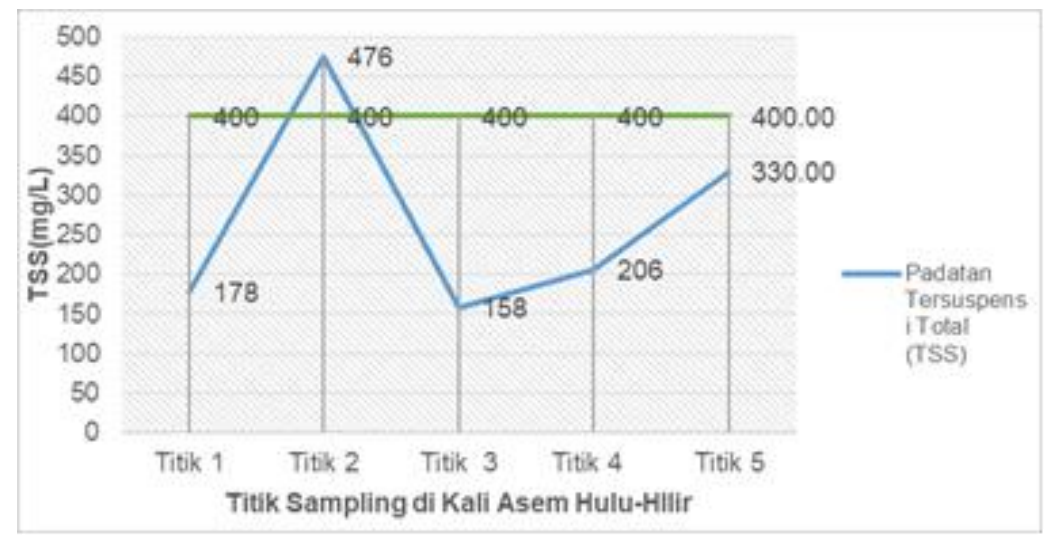

Gambar 5. Konsentrasi TSS Kali Asem dipengaruhi Aktifitas TPA dan sekitarnya. 


\section{Simpulan}

Berdasarkan hasil perhitungan Indeks Pencemaran menunjukkan bahwa kelas mutu dari bagian hulu titik sampling Kali Asem adalah cemar sedang, semakin ke hilir meningkat menjadi cemar berat. Adapun kualitas air lindi setelah melewati IPAS baik TPST Bantar Gebang maupun TPA Sumur Batu telah memenuhi Peraturan Menteri LHK Nomor P.59/Menlhk/Setjen/Kum.1/7/2016 Lampiran I Tentang Baku Mutu Lindi. Sehingga diperkirakan ada pengaruh kegiatan pemrosesan akhir sampah pada zona 3 TPST Bantar Gebang, zona gabungan TPST Bantarg Gebang, dan zona TPA Sumur Batu terhadap penurunan kualitas air Kali Asem, hal ini ditunjukan dengan hasil analisis kualitas air Kali Asem terutama BOD dan COD pada semua titik sampling melebihi baku mutu yang telah ditetapkan.

\section{Daftar Pustaka}

Azwar Ali. (2013). Strategi Pengelolaan Air Sungai di Sungai Metro Kecamatan Sukun Kota Malang. Tesis. Malang: Universitas Brawijaya

BPS Kabupaten Bekasi. (2014). Kabupaten Dalam Angka 2014. Bekasi: BPS Kabupaten Bekasi.

Bukit TN, Yusuf IA. (2001). Beban Pencemaran Limbah Industri dan Status Kualitas Air Sungai Citarum. Jurnal teknologi Lingkungan, 3(3), 98-106.

Cahyaningsih A, Harsoyo B. (2010). Distribusi Spasial Tingkat Pencemaran Air di DAS Citarum. Jurnal Sains \& Teknologi Modifikasi Cuaca, 11(2), 1-9.

Effendi, H. (2003). Telaah Kualitas Air: Bagi Pengelolaan Sumber Daya Alam dan Lingkungan Perairan. Yogyakarta: Penerbit Kanisius.

Haynes, T. B., Rosenberger, A. E., Lindberg, M. S., Whitman, M., \& Schmutz, J. A. (2014). Patterns of lake occupancy by fish indicate different adaptations to life in a harsh Arctic environment. Freshwater Biology, 59(9), 1884-1896.

MLH. (2003). Keputusan Menteri Lingkungan Hidup No 110 Tahun 2003 Pedoman Penetapan Daya Tampung Beban Pencemaran Air pada Sumber Air. Jakarta-Indonesia: Menteri Lingkungan Hidup.

MLH. (2003). Keputusan Menteri Lingkungan Hidup No. 115 Tahun 2003 Tentang Pedoman Penentuan Status Mutu Air. Jakarta-Indonesia: Menteri Lingkungan Hidup.

MLHK. (2016). Peraturan Menteri Lingkungan Hidup dan Kehutanan Nomor P.59/Menlhk/Setjen/Kum.1/7/2016 Lampiran I Tentang Baku Mutu Lindi. Jakarta-Indonesia: Menteri Lingkungan Hidup dan Kehutanan.

Sofia Y, Tantowi, Rahayu S. (2010). Penelitian Pengolahan Air Sungai yang tercemar oleh Bahan Organik. Jurnal Sumber daya Air, 6(2), 103 - 204. 